\title{
Menstrual and Reproductive Function in Women with HIV-infection and Antioxidant Vitamins Deficiency
}

Lubov I Kolesnikova, Sergey I Kolesnikov, Marina A Darenskaya", Lyudmila A Grebenkina, Elena Timofeeva, Olga Ya Leshenko and Olga Vanteeva Scientific Centre for Family Health and Human Reproduction Problems (SC FH a HRP), Siberian Branch, Russian Academy of Medical Sciences (SB RAMS), Russia

*Corresponding author: Marina A. Darenskaya, Scientific Centre for Family Health and Human Reproduction Problems (SC FH a HRP), 16, Timiryasev str. Irkutsk. 664003 Russian Federation, Tel: +79642275272; E-mail: mops_my@front.ru

Received date: October 28, 2014; Accepted date: November 19, 2014; Published date: November 25, 2014

Copyright: (C) 2014 Kolesnikova LI, et al. This is an open-access article distributed under the terms of the Creative Commons Attribution License, which permits unrestricted use, distribution, and reproduction in any medium, provided the original author and source are credited.

\begin{abstract}
Reproductive age women proportion with HIV-infection increasing, but relationship of antioxidant deficiency and reproductive disorders in this category of patients remain unclear. Objective: To identify antioxidant vitamins deficiency and frequency of reproductive disorders interrelations in women with HIV-infection. 53 women of reproductive age with HIV-infection were divided for 4 groups according to blood serum vitamins concentration: 36 women - $\alpha$-tocopherol level less than $12 \mu \mathrm{mol} / \mathrm{L} ; 17$ women - $\alpha$-tocopherol level in the range 12-24 $\mu \mathrm{mol} / \mathrm{L} ; 35$ women with retinol level less than $1.05 \mu \mathrm{mol} / \mathrm{L}$ and 18 women - retinol level in the range $1.05-2.8 \mu \mathrm{mol} / \mathrm{L}$. Spectral fluorofotometric methods were used. Statistical analysis was performed by parametric and non-parametric methods. High incidence of menstrual disorders $(63 \%)$, infertility $(36.1 \%)$, and luteal phase deficiency was found in the group of women with HIV-infection and a-tocopherol deficiency. Elevated levels of primary lipid peroxidation (LP) products - diene conjugates, with the absence of significant differences in the content of the thiobarbituric acid reactants in this group were registered. The results obtained showed a close relationship of a-tocopherol deficiency and disorders of the reproductive system in women with HIV-infection. It is a significant reason to recommend including of antioxidant drugs in HIV-women patients of complex pathogenetic therapy to regulate adequately their reproductive function and possibly to preserve reproductive ability in these women.
\end{abstract}

Keywords: HIV-infection; Reproductive disorders; Antioxidant vitamins; Tocopherol; Retinol

\section{Background}

According to the Federal Research and Methodological Center for Prevention and Control of AIDS in the Russian Federation currently registered 246,000 $\mathrm{HIV}$-infected women and $4398 \mathrm{HIV}$-infected children born by infected mothers. In the age groups 15-19 and 20-24 years there excess cases of HIV-infection among women compared with men registered since 2009. Since 2005 percentage of heterosexually acquired HIV among women is constantly growing $61 \%$. Irkutsk Region has unfavorable epidemiological situation of HIV-infection (more than 30 thousand people), with dramatically increasing proportion of HIV-infected women, sexual route of infection prevails [1].

There are numerous studies showing increased frequency of disturbances of the menstrual cycle and ovulation [2,3], decrease in ovarian reserve [4], endocrine pathology and hypogonadism among HIV-positive women compared to HIV-negative women $[5,6]$. Number of ovulatory cycles and coital frequency correlate with severity of HIV/AIDS clinical status and obviously could impact fertility, and may reflect the degree of wasting and immunosuppression in AIDS [7]. Increased persistence of the human papilloma virus infection, with dysplasia and cervical cancer development $[8,9]$, genital infections, with the further occurrence of acute or chronic inflammatory diseases of the pelvic organs [10] have been registered in women with HIV-infection. Among HIV-positive women, higher viral loads and lower CD4 counts were associated with increased cycle variability and polymenorrhea [11]. It is believed that
HIV serostatus is associated with prolonged amenorrhea [2]. Highly active anti-retroviral therapy (HAART) use was not associated with prevalent abnormalities, but both HAART use and higher CD4 counts were linked to lower incidence of menstrual problems [12]. Some animal studies indicate that HAART may decrease reproductive competence. It was shown that cigarette smoking, alcohol and illicit drugs associated with a poorer response to antiretroviral therapy in women with HIV-infection [13]. Fertility and birth rates among women with HIV-1 infection are lower and the rate of early termination higher than for the general population [14].

Systemizing and identification of molecular biomarkers as reference points for the diagnosis, prevention and treatment of various disorders is of special importance [15,16]. Antioxidant defense system (AOS) is one of the key systems responsible for protecting the body from the adverse effects of both external and internal factors [17-19]. The most potent natural antioxidants are considered lipid soluble vitamins - $\alpha$ tocopherol and retinol [20]. These vitamins, being elements of AOS, prevent the development of oxidative stress (OS). Several studies show the relationship of antioxidant deficiency and the reproductive system of women, due to their involvement in the work of all parts of the regulation of pituitary gonadotrophic function $[18,19]$. $\alpha$-tocopherol, as antioxidant effects the reproductive system state, stimulates ovaries steroidogenesis, endometrium protein biosynthesis and influence other steroid hormones synthesis target organs [19].

\section{Objective}

To identify antioxidant vitamins deficiency and frequency of reproductive disorders interrelations in women with HIV-infection 
Citation: Kolesnikova LI, Kolesnikov SI, Darenskaya MA, Grebenkina LA, Timofeeva E, et al. (2014) Menstrual and Reproductive Function in Women with HIV-infection and Antioxidant Vitamins Deficiency. J AIDS Clin Res 5: 382. doi:10.4172/2155-6113.1000382

Page 2 of 5

\section{Methods}

The study was performed in 2012-2014 period according to ethical standards of Helsinki Declaration (2008) in the Scientific Centre for Family Health and Human Reproduction Problems, Russian Academy of Medical Sciences (Irkutsk, Russia), Irkutsk regional infections hospital and Irkutsk regional AIDS Centre. This study was approved by the Ethic Committee of Scientific Centre of Family Health and Human Reproduction Problems (Siberian Branch of RAMS), and all involved patients signed the Informed Consent agreement for participation in the study. A random sample of women aged 18-40 years with HIV-infection from Irkutsk was carried out. The inclusion criteria: reproductive age, confirmed HIV carriers, informed consent for investigations. Exclusion criteria: excessive weight, the presence of tuberculosis, diabetes mellitus. Patients underwent interview included demographic, medical, nutritional and recreational drug-related questionnaires. A physical and anthropometrics examination performed.

53 women with HIV-infection (mean age $-31.13 \pm 4.49$ years) were included in the investigations. They were divided into four groups depending on vitamins in blood serum content (36 women - $\alpha$ tocopherol level less than $12 \mu \mathrm{mol} / \mathrm{L}$ (1 group); 17 women $\alpha$ tocopherol level in the range $12-24 \mu \mathrm{mol} / \mathrm{L}$ (2 group); 35 women with retinol level less than $1.05 \mu \mathrm{mol} / \mathrm{L}$ ( 3 group) and 18 women - retinol level in the range 1.05-2.8 $\mu \mathrm{mol} / \mathrm{L}$ (4 group)). $12-24 \mu \mathrm{mol} / \mathrm{L} \alpha-$ tocopherol, and 1.05-2.8 $\mu \mathrm{mol} / \mathrm{L}$ retinol levels - were taken as standards [21].

Blood samples were obtained to confirm HIV, hepatitis B virus status, hepatitis $\mathrm{C}$ virus, to determine CD4 cell count, HIV viral load, complete blood cell count and blood biochemistry, including the serum concentrations of antioxidant parameters ( $\alpha$-tocoferol, retinol) and parameters of oxidative stress (plasma conjugated dienes (CDs) and thiobarbituric acid reactants (TBARs)) after overnight fasting. Lymphocyte phenotype was determined with a four-colored monoclonal antibodies immune phenotyping panel. Differential counts were determined with a cytometric method using a FacsCount (Becton Dickinson, USA). HIV viral load was obtained by reverse transcriptase-polymerase chain reaction. Patient's blood samples centrifuged for $5 \mathrm{~min}$ at $1.500 \mathrm{~g}$ at $4^{\circ} \mathrm{C}$; and erythrocytes were rinsed three times with $\mathrm{NaCl} 0.9 \%$ (wt/vol).

$\mathrm{CD}_{\mathrm{s}}$ absorbance detected in plasma heptanes extracts at $232 \mathrm{~nm}$ [22]. For conversion of absorption units to $\mu \mathrm{mol} / \mathrm{L}$ coefficient of molar absorption ( $\mathrm{K}=2.2105 \mathrm{M}-1 \mathrm{C}-1)$ was used. TBARs levels were detected by fluorometry [23] end estimated in $\mu \mathrm{mol} / \mathrm{L}$. $\alpha$-tocopherol and retinol levels were detected in serum by fluorometry [24].

Body mass index (BMI) was calculated using the standard formula that divides weight in kilograms by the square of height in meters $\left(\mathrm{kg} / \mathrm{m}^{2}\right)$.

Levels of hormones in the serum were evaluated with ELISA and radioimmunoassay devices: "Immunoassay" (Russia), Elx808 Ultra Microplate Reader Bio-Tek Instruments, ins (USA). Several instrumental methods: colposcopy, pelvic, thyroid and mammary glands ultrasound investigations on the device "ALOKA-650" were used. Human papillomavirus was detected by the method of DNA amplification or the polymerase chain reaction.

Statistical analysis was performed by STATISTICA 6.1 software (Stat-Soft Inc., USA). To compare the frequency of occurrence - using z-test or Fisher's exact test. Means and standard deviation (SD) of means were calculated and significance of differences between values was evaluated by Student (T-test) and Mann-Whitney (U-test) tests. The level of significance was set at $\mathrm{p}<0.05$.

\section{Results}

Group's characteristics are shown in a Table 1. Occurrence frequency of patients with hepatitis was differences in groups 1 and 2 . In group $1 \mathrm{HIV} /$ hepatitis $\mathrm{B}+\mathrm{C}$ combination was significantly more often - 12 cases $(33.3 \%)$ compared to group 2 - 1 case $(5.9 \%)(p<0.05)$. There were no significant differences in ages, BMI, alcohol consumption, cigarette smoking, and illicit drugs consumption $(\mathrm{p}>0.05)$. There were no significant differences in those who received highly active antiretroviral therapy (HAART) between groups $(\mathrm{p}>0.05)$.

\begin{tabular}{|c|c|c|c|c|c|c|}
\hline \multirow[b]{2}{*}{ Parameter } & \multicolumn{2}{|l|}{$\alpha$-tocoferol, $\mu \mathrm{mol} / \mathrm{L}$} & \multirow[t]{2}{*}{ P-value } & \multicolumn{2}{|c|}{ Retinol, $\mu \mathrm{mol} / \mathrm{L}$} & \multirow[t]{2}{*}{ P-value } \\
\hline & $\begin{array}{l}<12 \mu \mathrm{mol} / \mathrm{L}(\mathrm{n}=36) \\
\text { (1) }\end{array}$ & $\begin{array}{l}12-42 \mu \mathrm{mol} / \mathrm{L}(\mathrm{n}=17) \\
(2)\end{array}$ & & $\begin{array}{l}<1.05 \mu \mathrm{mol} / \mathrm{L} \\
(\mathrm{n}=35) \\
(3)\end{array}$ & $\begin{array}{l}1.05-2.8 \mu \mathrm{mol} / \mathrm{L} \\
(\mathrm{n}=18) \\
(4)\end{array}$ & \\
\hline $\begin{array}{l}\text { Age (years) (mean } \pm \\
\text { SD) }\end{array}$ & $31.4 \pm 3.9$ & $30.5 \pm 5.6$ & 0.467 & $31.6 \pm 4.6$ & $30.3 \pm 4.3$ & 0.326 \\
\hline $\begin{array}{l}\text { BMI }\left(\mathrm{kg} / \mathrm{m}^{2}\right) \text { (mean } \pm \\
\text { SD) }\end{array}$ & $19.4 \pm 2.9$ & $20.4 \pm 3.6$ & 0.305 & $19.7 \pm 3.5$ & $19.7 \pm 2.5$ & 0.959 \\
\hline $\begin{array}{l}\text { Frequent alcohol use } \\
\text { (>2 drinks daily) }(\%(n)\end{array}$ & $34.3 \%(10)$ & $44.4 \%(8)$ & 0.239 & $35.3 \%(12)$ & $52.6 \%(10)$ & 0.155 \\
\hline $\begin{array}{l}\text { Frequent cigarette use } \\
\text { (>1 pack daily) }(\%(\mathrm{n})\end{array}$ & $46.9 \%(15)$ & $47.6 \%(10)$ & 1.000 & $23.5 \%(8)$ & $47.4 \%(9)$ & 0.064 \\
\hline $\begin{array}{l}\text { Injecting illicit drug use } \\
(\%(n))\end{array}$ & $22.2 \%(8)$ & $41.2 \%(7)$ & 0.197 & $17.1 \%(6)$ & $38.9 \%(7)$ & 0.101 \\
\hline \multicolumn{7}{|l|}{ Hepatitis } \\
\hline B & $16.7 \%(6)$ & (0) & 0.160 & $14.3 \%(5)$ & $5.6 \%(1)$ & 0.651 \\
\hline
\end{tabular}


Citation: Kolesnikova LI, Kolesnikov SI, Darenskaya MA, Grebenkina LA, Timofeeva E, et al. (2014) Menstrual and Reproductive Function in Women with HIV-infection and Antioxidant Vitamins Deficiency. J AIDS Clin Res 5: 382. doi:10.4172/2155-6113.1000382

Page 3 of 5

\begin{tabular}{|l|l|l|l|l|l|l|}
\hline C & $19.4 \%(7)$ & $17.6 \%(3)$ & 1.000 & $17.1 \%(6)$ & $22.2 \%(4)$ & 0.719 \\
\hline B+C & $33.3 \%(12)$ & $5.9 \%(1)$ & $0.041^{*}$ & $14.3 \%(5)$ & $33.3 \%(6)$ & 0.154 \\
\hline $\begin{array}{l}\text { Receiving HAART }(\% \\
\text { (n)) }\end{array}$ & $30.6 \%(11)$ & $52.9 \%(9)$ & 0.233 & $35.3 \%(12)$ & $42.1 \%(8)$ & 0.911 \\
\hline
\end{tabular}

Table 1: Characteristics of Patients of Four Groups. * significant differences.

Laboratory data are shown in a Table 2. Albumin level was significantly lower in the 1 groups $(39.5 \pm 5.1 \mathrm{~g} / \mathrm{dL})$ than in those who were in the 2 groups $(44.9 \pm 14.7 \mathrm{~g} / \mathrm{dL})(\mathrm{p}<0.05)$. There were no significant differences in $\mathrm{CD}^{+}$cell counts and HIV viral loads
( $p>0.05)$. There were also no statistically significant differences between the groups in their levels of alanine aminotransferase (ALT), aspartate aminotransferase (AST), hemoglobin, plasma bilirubin $(\mathrm{p}>0.05)$.

\begin{tabular}{|c|c|c|c|c|c|c|}
\hline \multirow[t]{2}{*}{ Parameter } & \multicolumn{2}{|l|}{$\alpha$-tocoferol, $\mu \mathrm{mol} / \mathrm{L}$} & \multirow[t]{2}{*}{ P-value } & \multicolumn{2}{|c|}{ Retinol, $\mu \mathrm{mol} / \mathrm{L}$} & \multirow[t]{2}{*}{ P-value } \\
\hline & $\begin{array}{l}<12 \mu \mathrm{mol} / \mathrm{L}(\mathrm{n}=36) \\
(1)\end{array}$ & $\begin{array}{l}12-42 \\
\mu \mathrm{mol} / \mathrm{L}(\mathrm{n}=17) \\
(2)\end{array}$ & & $\begin{array}{l}<1.05 \mu \mathrm{mol} / \mathrm{L} \\
(\mathrm{n}=35) \\
(3)\end{array}$ & $\begin{array}{l}1.05-2.8 \mu \mathrm{mol} / \mathrm{L} \\
(\mathrm{n}=18) \\
(4)\end{array}$ & \\
\hline $\begin{array}{l}\text { Viral load } \quad(\log 10 \\
\text { copies } / \mathrm{mL}) \\
(\text { mean } \pm \mathrm{SD})\end{array}$ & $5.4 \pm 2.4$ & $1.8 \pm 0.5$ & 0.276 & $3.2 \pm 1.1$ & $4.8 \pm 1.2$ & 0.382 \\
\hline $\begin{array}{lr}\mathrm{CD} 4+ & \text { count } \\
\text { (cells } / \mathrm{mL}) & \text { (mean } \\
\pm \mathrm{SD}) & \end{array}$ & $89.8 \pm 47.9$ & $114.6 \pm 110.7$ & 0.384 & $102.3 \pm 95.1$ & $88.8 \pm 52.8$ & 0.632 \\
\hline $\begin{array}{l}\text { AST } \quad(I U / L) \quad \text { (mean } \\
\pm \text { SD) }\end{array}$ & $78.3 \pm 68.1$ & $45.5 \pm 20.0$ & 0.058 & $77.3 \pm 69.3$ & $49.3 \pm 26.1$ & 0.103 \\
\hline $\begin{array}{l}\mathrm{ALT} \quad(\mathrm{IU} / \mathrm{L}) \quad(\text { mean } \\
\pm \mathrm{SD})\end{array}$ & $55.9 \pm 22.8$ & $45.5 \pm 37.5$ & 0.588 & $62.0 \pm 57.2$ & $41.8 \pm 20.1$ & 0.140 \\
\hline $\begin{array}{l}\text { Albumin } \\
(\text { mean } \pm S D)\end{array}$ & $39.5 \pm 5.1$ & $44.9 \pm 14.7$ & $0.047^{*}$ & $39.7 \pm 5.2$ & $44.2 \pm 15.2$ & 0.100 \\
\hline $\begin{array}{l}\text { Bilirubin } \\
(m e a n \pm S D)\end{array} \quad(m g / d L)$ & $19.9 \pm 11.6$ & $13.1 \pm 8.9$ & 0.373 & $17.9 \pm 11.2$ & $17.5 \pm 12.3$ & 0.955 \\
\hline $\begin{array}{l}\mathrm{Hgb} \quad(\mathrm{g} / \mathrm{dL}) \quad(\text { mean } \\
\pm \mathrm{SD})\end{array}$ & $110.3 \pm 14.1$ & $113.5 \pm 10.4$ & 0.403 & $111.7 \pm 14.1$ & $110.5 \pm 12.3$ & 0.746 \\
\hline
\end{tabular}

Table 2: Laboratory Parameters Value in Four Groups. ${ }^{*}$ significant differences.

Features of the menstrual and reproductive function of women surveyed are presented in Table 3. Menstrual cycle disorders were significantly more common in patients of group 1 compared with group $2(63.9 \%$ vs. $35.3 \%, \mathrm{p}<0.05)$. Reproductive history of women with HIV reviled high incidence of total infertility cases in group 1 $(36.1 \%$ vs. $11.8 \%$ in the 2 group, $\mathrm{p}<0.05)$, in this case, the prevailing primary infertility - in $22.2 \%(\mathrm{p}<0.05)$. Significant differences were recorded in the frequency of luteal phase deficiency - $61.1 \%$ vs. $47.1 \%$, $\mathrm{p}<0.05$ - between the 1 and 2 groups. Significant differences in frequency of amenorrhea, oligomenorrhea, opsomenorrhea, secondary infertility and structure of the causes of infertility in group 1 compared to group 2 data were not established ( $p>0.05)$. 3 and 4 groups had no differences in both the total number of women with menstrual irregularities, and individual diseases $(\mathrm{p}>0.05)$. There were also no significant differences in the frequency of presence infertility and structure of the causes of infertility $(p>0.05)$.

\section{Discussion}

It was suggested that OS may have pathological roles in development of HIV-infection [25]. It has been established that OS induces the initial stages of apoptosis, which contributes to the depletion of $\mathrm{T}$ cells and the progression of HIV-infection [26]. OS often occurs due to decreased activity of the antioxidant deficiency system that is typical for HIV-infection endogenous intoxication syndrome. We found primary LP products - diene conjugates increasing in women with HIV-infection and a-tocopherol deficiency. Formation and accumulation of conjugated dienes affects the permeability of membranes, and membrane-associated activity of enzymes and ion transport. This effect is the loss of membrane barrier functions which is the basis of the pathogenesis of reproductive disorders, including infertility [27]. It is believed that LP products acting on the diaphragm gametes violate its fluidity apoptotic processes in a cell and may cause infertility $[28,29]$.

Our study proved that women with HIV and a-tocopherol deficiency have higher level of the reproductive system disorders 
Citation: Kolesnikova LI, Kolesnikov SI, Darenskaya MA, Grebenkina LA, Timofeeva E, et al. (2014) Menstrual and Reproductive Function in

Page 4 of 5

(incidence of menstrual disorders, infertility, and a high percentage of failure of the luteal phase) than in the group with normal vitamin content. It is known that $a$-tocopherol affects various parts of the reproductive system and its deficiency certainly has pathogenetic importance in the development of infertility [19,30]. Thus, reduced levels of a-tocopherol may contribute to the development of reproductive disorders in women with HIV-infection.

\begin{tabular}{|c|c|c|c|c|c|c|}
\hline \multirow[t]{2}{*}{ Parameter } & \multicolumn{2}{|l|}{$\alpha$-tocoferol, $\mu \mathrm{mol} / \mathrm{L}$} & \multirow[t]{2}{*}{ P-value } & \multicolumn{2}{|c|}{ Retinol, $\mu \mathrm{mol} / \mathrm{L}$} & \multirow[t]{2}{*}{ P-value } \\
\hline & $\begin{array}{l}<12 \mu \mathrm{mol} / \mathrm{L}(\mathrm{n}=36) \\
\text { (1) }\end{array}$ & $\begin{array}{l}12-42 \\
\mu \mathrm{mol} / \mathrm{L}(\mathrm{n}=17) \\
(2)\end{array}$ & & $\begin{array}{l}<1.05 \mu \mathrm{mol} / \mathrm{L} \\
(\mathrm{n}=35) \\
(3)\end{array}$ & $\begin{array}{l}1.05-2.8 \mu \mathrm{mol} / \mathrm{L} \\
(\mathrm{n}=18) \\
(4)\end{array}$ & \\
\hline Menstrual cycle disorders & $63.9 \%(23)$ & $35.3 \%(6)$ & $0.045^{*}$ & $48.6 \%(17)$ & $66.7 \%(12)$ & 0.254 \\
\hline Amenorrhea & $19.4 \%(7)$ & $5.9 \%(1)$ & 0.412 & $11.4 \%(4)$ & $22.2 \%(4)$ & 0.421 \\
\hline Oligomenorrhea & $36.1 \%(13)$ & $29.4 \%(5)$ & 0.760 & $34.3 \%(12)$ & $33.3 \%(6)$ & 1.000 \\
\hline Opsomenorrhea & $19.4 \%(7)$ & $23.5 \%(4)$ & 0.730 & $14.3 \%(5)$ & $33.3 \%(6)$ & 0.154 \\
\hline $\begin{array}{l}\text { The presence of total } \\
\text { infertility }\end{array}$ & $36.1 \%(14)$ & $11.8 \%(2)$ & $0.048^{*}$ & $28.6 \%(10)$ & $27.8 \%(5)$ & 1.000 \\
\hline Primary & $22.2 \%(8)$ & (0) & $0.044^{*}$ & $17.1 \%(6)$ & $5.6 \%(1)$ & 0.401 \\
\hline Secondary & $17.1 \%(6)$ & $11.8 \%(2)$ & 1.000 & $11.4 \%(4)$ & $22.2 \%(4)$ & 0.421 \\
\hline \multicolumn{7}{|c|}{ Structure of the causes of infertility } \\
\hline Tubal-peritoneal Factor & $2.8 \%(1)$ & (0) & 1.000 & $25.7 \%(9)$ & $22.2 \%(4)$ & 1.000 \\
\hline Endocrine infertility & $30.6 \%(11)$ & $11.8 \%(2)$ & 0.163 & $25.7 \%(9)$ & $22.2 \%(4)$ & 1.000 \\
\hline Uterine factor & $13.9 \%(5)$ & (0) & 0.159 & $11.4 \%(4)$ & $5.6 \%(1)$ & 0.651 \\
\hline Luteal phase deficiency & $61.1 \%(22)$ & $47.1 \%(8)$ & $0.001^{*}$ & $54.3 \%(19)$ & $61.1 \%(11)$ & 0.772 \\
\hline Decreased ovarial reserve & $11.1 \%(4)$ & $11.8 \%(2)$ & 1.000 & $11.4 \%(4)$ & $11.1 \%(2)$ & 1.000 \\
\hline
\end{tabular}

Table 3: Characteristics of Menstrual and Reproductive Function in Four Groups. *significant differences.

Levels of CDs and TBARs prove the presence of oxidative stress. Table 4 demonstrates that the CDs mean level is significantly higher $(1.8 \pm 0.9 \mu \mathrm{mol} / \mathrm{L})$ in group 1 patients than those in group $2(1.3 \pm 0.7$

$\mu \mathrm{mol} / \mathrm{L}) \quad(\mathrm{p}<0.05)$. No TBARs levels differences between groups registered $(\mathrm{p}>0.05)$ (Table 4$)$.

\begin{tabular}{|c|c|c|c|c|c|c|}
\hline \multirow[t]{2}{*}{ Blood Parameter } & \multicolumn{2}{|l|}{$\alpha$-tocoferol, $\mu \mathrm{mol} / \mathrm{L}$} & \multirow[t]{2}{*}{ P-value } & \multicolumn{2}{|c|}{ Retinol, $\mu \mathrm{mol} / \mathrm{L}$} & \multirow[t]{2}{*}{ P-value } \\
\hline & $\begin{array}{l}<12 \mu \mathrm{mol} / \mathrm{L}(\mathrm{n}=36) \\
\text { (1) }\end{array}$ & $\begin{array}{l}12-42 \mu \mathrm{mol} / \mathrm{L}(\mathrm{n}=17) \\
(2)\end{array}$ & & $\begin{array}{l}<1.05 \mu \mathrm{mol} / \mathrm{L} \\
(\mathrm{n}=35) \\
(3)\end{array}$ & $\begin{array}{l}1.05-2.8 \mu \mathrm{mol} / \mathrm{L} \\
(\mathrm{n}=18) \\
(4)\end{array}$ & \\
\hline $\mathrm{CDs}(\mu \mathrm{mol} / \mathrm{L})$ & $1.8 \pm 0.9$ & $1.3 \pm 0.7$ & $0.043^{*}$ & $1.6 \pm 0.9$ & $1.6 \pm 1.0$ & 0.949 \\
\hline TBARs $(\mu \mathrm{mol} / \mathrm{L})$ & $1.03 \pm 0.7$ & $0.9 \pm 0.5$ & 0.479 & $1.0 \pm 0.7$ & $0.9 \pm 0.6$ & 0.820 \\
\hline
\end{tabular}

Table 4: Groups Differences of Oxidative Stress Parameters. All values are mean \pm SD. ${ }^{\star}$ - significant differences.

It is necessary specially emphasize the large number women with $\mathrm{HIV} /$ hepatitis B and C co-infection in the group with a-tocopherol deficiency. Information on combined effects of blood-borne viral hepatitis and HIV-infection on the reproductive health of women is scarce in the scientific literature [31-33]. Probably, the co-infection accompanying low antioxidant activity may contribute to the development of reproductive disorders in these patients and, moreover, HAART - therapy did not improve their status. We found downward trend $\mathrm{CD} 4^{+}$cells in this patients and lower albumin level due to the presence of $a$-tocopherol deficiency. The study also shows a tendency to viral load increase in women with HIV-infection and atocopherol deficiency, probably due to the presence the large number women with $\mathrm{HIV} /$ hepatitis B and C co-infection. Association between retinol levels and frequency of the menstrual and reproductive system disorders in women with HIV-infection was not found.

\section{Conclusions}

Our study found higher levels of the menstrual cycle and reproductive disorders were registered in women with HIV-infection 
and $\alpha$-tocopherol deficiency. It is a significant reason to recommend including of antioxidant drugs in HIV-women patients of complex pathogenetic therapy (HAART) to regulate adequately their reproductive function and possibly to preserve reproductive ability in these women. Antioxidant vitamins deficiency correction proposed to avoid reproductive disorders progressing. In this respect, further research is needed.

\section{Acknowledgement}

This study was supported by a grant from President of Russian Federation (NO-4656.2014.7).

\section{References}

1. Kolesnikova LI, Suturina LV, Labigina AV, Leshenko OY, Fiodorov BA, et al. (2007) Abnormalities of reproductive health and reproductive potential in present-day conditions of Eastern Siberia. Bulletin of the East-Siberian Scientific Center of the SB RAMS 2: 41-43.

2. Clark RA, Mulligan K (2001) Frequency of Anovulation and Early Menopause among Women Enrolled in Selected Adult AIDS Clinical Trials Group Studies. J Infect Dis 184: 1325-1327.

3. Cejtin HE (2008) Gynecologic issues in the HIV-infected woman. Infect Dis Clin North Am 22: 709-739, vii.

4. Seifer DB, Golub ET, Lambert-Messerlian G, Springer G, Holman S, et al. (2007) Biologic markers of ovarian reserve and reproductive aging: application in a cohort study of HIV infection in women. Fertil Steril 88: 1645-1652.

5. Kalra S, Sleim H, Kotwal N (2011) Human immunodeficiency virus and the endocrine system. Indian J Endocrinol Metab 15: 231-233.

6. Baecher-Lind LE, Miller WC, Wilcox AJ (2010) Infectious disease and reproductive health: a review. Obstet Gynecol Surv 65: 53-65.

7. Kushnir VA, Lewis W (2011) Human immunodeficiency virus/acquired immunodeficiency syndrome and infertility: emerging problems in the era of highly active antiretrovirals. Fertil Steril 96: 546-553.

8. Singh DK, Anastos K, Hoover DR, Burk RD, Shi Q, et al. (2009) Human papillomavirus infection and cervical cytology in HIV-infected and HIVuninfected Rwandan women. J Infect Dis 199: 1851-1861.

9. Abdoulaye S, Joseph EE, Privat G, Hamdan KS, Mamadou K, et al. (2014) Dermatologist Contribution to Early Detection and Management of the Precancerous Lesions (PCL) of the Cervix in HIV Positive Patients: A Study in a Country with Limited Resources. J AIDS Clin Res 5: 287.

10. Irwin KL, Moorman AC, O'Sullivan MJ, Sperling R, Koestler ME, et al. (2000) Influence of human immunodeficiency virus infection on pelvic inflammatory disease. Obstet Gynecol 95: 525-534.

11. Harlow SD, Schuman P, Cohen M, Ohmit SE, Cu-Uvin S, et al. (2000) Effect of HIV infection on menstrual cycle length. J Acquir Immune Defic Syndr 24: 68-75

12. Massad LS, Evans CT, Minkoff H, Watts DH, Greenblatt RM, et al. (2006) Effects of HIV infection and its treatment on self-reported menstrual abnormalities in women. J Womens Health (Larchmt) 15: 591-598.

13. Loutfy MR, Sherr L, Sonnenberg-Schwan U, Walmsley SL, Johnson M, et al. (2013) Caring for women living with HIV: gaps in the evidence. J Int AIDS Soc 16: 18509.

14. Thackway SV, Furner V, Mijch A, Cooper DA, Holland D, et al. (1997) Fertility and reproductive choice in women with HIV-1 infection. AIDS 11: 663-667.
15. Fedorov BA, Kolesnikova LI, Suturina LV, Sholokhov LF, Grebenkina LA, et al. (2011) The state of hormonal-metabolic homeostasis in women of reproductive age with viral hepatitis B and C. Fundamental Research 2: 157-160.

16. Semeniuk AV, Kolesnikova LI, Kulikov VJ, Nedel'kina SV, Salganik RI (1982) Activity assessment method metabolizing enzymes drug compounds. Clinical laboratory diagnostics 10: 607-609.

17. Kolesnikova LI, Darenskaya MA, Grebenkina LA, Labygina AV, Suturina LV, et al. (2012) Activity of lipid peroxidation in infertile women from different populations. Bull Exp Biol Med 154: 203-205.

18. Darenskaya MA, Kolesnikova LI, Bardimova TP, Petrova VA, Dolgikh MI, et al. (2006) Changes in parameters of lipid peroxidation process in healthy people in different age periods of reproductive system formation. Bulletin of the East-Siberian Scientific Center of the SB RAMS 1: 119-122.

19. Kolesnikova LI, Darenskaia MA, Grebenkina LA, Suturina LV, Labygina AV, et al. (2012) [Characteristics of the antioxidant system of healthy people of main ethnic groups living near Baikal Lake]. Vopr Pitan 81: 46-51.

20. Agarwal A, Kashou AH (2011) Oxidants and Antioxidants in the Pathogenesis of HIV/AID. The Open Reproductive Science Journal 3: 154-161.

21. Wu A (2006) Tietz Clinical guide to laboratory tests. 1865.

22. Corongiu FP, Banni S (1994) Detection of conjugated dienes by second derivative ultraviolet spectrophotometry. Methods Enzymol 233: 303-310.

23. Yagy K (1982) Assay for serum lipid peroxide level and its clinical significance. Lipid Peroxides in Biology and Medicine. 223-242.

24. Cherniauskene RCh, Varshkiavichene ZZ, Gribauskas PS (1984) [Simultaneous fluorometric determination of the concentrations of vitamins $\mathrm{E}$ and A in blood serum]. Lab Delo : 362-365.

25. Kolesnikova LI, Grebenkina LA, Darenskaya MA, Vlasov BJ (2012) Oxidative stress as a non-specific pathogenetic link reproductive disorders (Review). Bulletin of the Siberian Branch of the Russian Academy of Medical Sciences 32: 58-66.

26. Pasupathi P, Ramchandran T, Sindhu PJ, Saranavan G, Bakthavathsalam G (2009) Enhanced Oxidative Stress Markers and Antioxidant Imbalance in HIV Infection and AIDS Patients. Journal of Scientific Research 1: 131-160.

27. Agarwal A, Gupta S, Sharma R (2005) Oxidative stress and its implications in female infertility - a clinician's perspective. Reprod Biomed Online 11: 641-650.

28. Agarwal A, Saleh RA, Bedaiwy MA (2003) Role of reactive oxygen species in the pathophysiology of human reproduction. Fertil Steril 79: 829-843.

29. Brigelius-Flohé R, Galli F (2010) Vitamin E: a vitamin still awaiting the detection of its biological function. Mol Nutr Food Res 54: 583-587.

30. Kolesnikova LI, Petrova VA, Kornakova NV, Labigina AV, Suturina LV (2008) Lipid peroxidation and antioxidant state in women with endocrine factors of sterility. J Obstetity Women Dis LVII 52-56.

31. Landes M, Newell ML, Barlow P, Fiore S, Malyuta R, et al. (2008) Hepatitis B or hepatitis C coinfection in HIV-infected pregnant women in Europe. HIV Med 9: 526-534.

32. Singhatiraj E, Suri J, Goulston C (2012) HIV Co-Infections with Hepatitis $B$ and C. J AIDS Clinic Res S3: 2.

33. Parsons M, Campa A, Lai S, Li Y, Martinez JD, et al. (2013) Effect of GSTM1-Polymorphism on Disease Progression and Oxidative Stress in HIV Infection: Modulation by HIV/HCV Co-Infection and Alcohol Consumption. J AIDS Clin Res 4. 